\title{
Comparison of the Effects of Recombinant Human Insulin-like Growth Factor-I and Insulin on Glucose and Leucine Kinetics in Humans
}

\author{
Roland Laager, Ronald Ninnis, and Ulrich Keller \\ Departments of Research and Internal Medicine, University of Basel, Switzerland
}

\begin{abstract}
To compare the metabolic effects of elevated plasma concentrations of IGF-I and insulin, overnight-fasted normal subjects were studied twice, once receiving IGF-I and once insulin at doses that resulted in identical increases in glucose uptake during 8-h euglycemic clamping. Recombinant human IGF-I or insulin were infused in one group at high doses $(30 \mu \mathrm{g} / \mathrm{kg}$ per $\mathrm{h}$ IGF-I or $0.23 \mathrm{nmol} / \mathrm{kg}$ per $\mathrm{h}$ insulin) and in another group at low doses $(5 \mu \mathrm{g} / \mathrm{kg}$ per h IGF-I or $0.04 \mathrm{nmol} / \mathrm{kg}$ per $\mathrm{h}$ insulin). Glucose rate of disappearance (measured by $\left[6,6-D_{2}\right]-$ glucose infusions) increased from baseline by $239 \pm 16 \%$ during high dose IGF-I vs $197 \pm 18 \%$ during insulin $(P=0.021$ vs IGF-I). Hepatic glucose production decreased by $37 \pm 6 \%$ during high dose IGF-I vs $89 \pm 13 \%$ during insulin $(P=0.0028$ vs IGF-I). IGF-I suppressed whole body leucine flux $\left(\left[1-{ }^{13} \mathrm{C}\right]-\right.$ leucine infusion technique) more than insulin ( $42 \pm 4$ vs $32 \pm 3 \%$ during high doses, $P=\mathbf{0 . 0 0 8 2}$ ). Leucine oxidation rate decreased during high dose IGF-I more than during insulin (55 \pm 4 vs $32 \pm 6 \%, P=0.0001)$. The decreases of plasma concentrations of free fatty acids, acetoacetate, and $\beta$-hydroxybutyrate after $8 \mathrm{~h}$ of IGF-I and insulin administration were similar. Plasma $C$-peptide levels decreased by $57 \pm 4 \%$ during high doses of IGF-I vs 36 $\pm 6 \%$ during insulin $(P=0.005$ vs IGF-I $)$. The present data demonstrate that, compared to insulin, an acute increase in plasma IGF-I levels results in preferential enhancement of peripheral glucose utilization, diminished suppression of hepatic glucose production, augmented decrease of whole body protein breakdown (leucine flux), and of irreversible leucine catabolism but in similar antilipolytic effects. The data suggest that insulin-like effects of IGF-I in humans are mediated in part via IGF-I receptors and in part via insulin receptors. (J. Clin. Invest. 1993. 92:1903-1909.) Key words: C-peptide $\bullet$ proteolysis $\bullet$ hepatic glucose output $\bullet$ insulin secretion $\bullet$ free fatty acids
\end{abstract}

\section{Introduction}

IGF-I shares much structural homology with insulin (1), and the IGF-I receptor on the surface of target cells is largely homologous to that of insulin (2). Since recombinant human IGF-I has become available, a few studies have been performed to elucidate its metabolic effects in man (3-5). The dose-depen-

Address correspondence to Ulrich Keller, M.D., Departments of Research and Internal Medicine, Kantonsspital, Petersgraben 4, CH-4031 Basel, Switzerland.

Received for publication 6 October 1992 and in revised form 23 April 1993.

J. Clin. Invest.

(c) The American Society for Clinical Investigation, Inc.

0021-9738/93/10/1903/07 $\$ 2.00$

Volume 92, October 1993, 1903-1909 dence of insulin-like effects of IGF-I on glucose uptake, leucine kinetics, lipolysis, and insulin secretion has recently been assessed (5) in normal volunteers. Effects of IGF-I and insulin have been compared previously in vitro and in animals. Glucose utilization in dog muscle was relatively more sensitive to IGF-I than to insulin (6) whereas human adipose tissue was relatively insensitive to IGF-I (7). The observations suggested that IGF-I increased glucose utilization in muscle cells via IGFI receptors. Similarly, studies in rats demonstrated contrasting effects of IGF-I and insulin on hepatic glucose production and plasma nonesterified fatty acids (8). The present studies were performed to compare the effects of increased plasma concentrations of IGF-I and insulin on glucose, amino acid, and lipid metabolism and on glucoregulatory hormones in humans. Two doses of IGF-I and insulin that matched each other with regard to glucose uptake during euglycemic clamping were chosen.

\section{Methods}

Subjects. Written informed consent was obtained from 24 healthy male volunteers $25.8 \pm 3.8 \mathrm{yr}$ old (range $=20-34 \mathrm{yr}$ old) and with a body mass index of $22.3 \pm 1.5 \mathrm{~kg} / \mathrm{m}^{2}$ (range $\left.=19.6-23.5 \mathrm{~kg} / \mathrm{m}^{2}\right)$. Their medical history, a physical examination, and routine laboratory tests before the studies provided no evidence for cardiopulmonary, renal, hepatic, or metabolic diseases. The subjects were on no medication and did not perform vigorous exercise $24 \mathrm{~h}$ before the studies. The study protocol was reviewed and approved by the Ethical committee of the Basel University Hospital.

Procedures. At 7 a.m., after a 12-h fast, a Teflon cannula was placed into the right antecubital vein for infusions. A superficial dorsal vein of the right hand was cannulated in retrograde manner using a 21 -gauge butterfly needle for blood sampling. The hand was kept in a thermostat-controlled warming chamber at a temperature of $\sim 55^{\circ} \mathrm{C}$ to allow arterialization of venous blood (9). After obtaining two blood and breath samples drawn within 10-min intervals to determine background isotopic enrichment of plasma $\left[\mathrm{D}_{2}\right]$ glucose, $\left[{ }^{13} \mathrm{C}\right]$ leucine, and $\alpha$-ketoisocaproate $\left(\alpha\right.$-KIC), ${ }^{1}$ and of breath ${ }^{13} \mathrm{CO}_{2}$, priming doses of $16.6 \mu \mathrm{mol} / \mathrm{kg}\left[6,6-\mathrm{D}_{2}\right]$ glucose (98\% enriched, sterile, and pyrogenfree; Tracer Technology, Cambridge, MA), of $2 \mu \mathrm{mol} / \mathrm{kg}\left[1-{ }^{13} \mathrm{C}\right]-$ leucine (99\% enriched, sterile, and pyrogen-free; Tracer Technology), and of $3.5 \mu \mathrm{mol} / \mathrm{kg} \mathrm{NaH}{ }^{13} \mathrm{CO}_{3}(90 \%$ enriched, sterile, and pyrogenfree; KOR Isotopes, Cambridge, MA) were injected; thereafter, continuous infusions of $\left[6,6-\mathrm{D}_{2}\right]$ glucose $(0.22 \mu \mathrm{mol} / \mathrm{kg}$ per min $)$ and $\left[1-{ }^{13} \mathrm{C}\right]-$ leucine $(0.06 \mu \mathrm{mol} / \mathrm{kg}$ per $\mathrm{min})$ were started; the $\left[D_{2}\right]$ glucose infusion rate was decreased during the period of glucose clamping in the low dose protocols to $0.11 \mu \mathrm{mol} / \mathrm{kg}$ per min and to 0 in the high dose protocols. After $120 \mathrm{~min}$ of tracer equilibration, blood and breath samples were obtained in 15-min intervals during a 30-min baseline period, then hourly and during the last $2 \mathrm{~h}$, they were obtained in 30-min intervals. The subjects were randomly allocated to one of three groups ( $n=8$ each) receiving infusion of either $30 \mu \mathrm{g} / \mathrm{kg}$ per h $(3.92 \mathrm{nmol} / \mathrm{kg}$ per h) IGF-I (high dose group), $5 \mu \mathrm{g} / \mathrm{kg}$ per h $(0.65 \mathrm{nmol} / \mathrm{kg}$ per h $)$

1. Abbreviations used in this paper: $\alpha$-KIC, $\alpha$-ketoisocaproate; MPE, mole percent excess. 


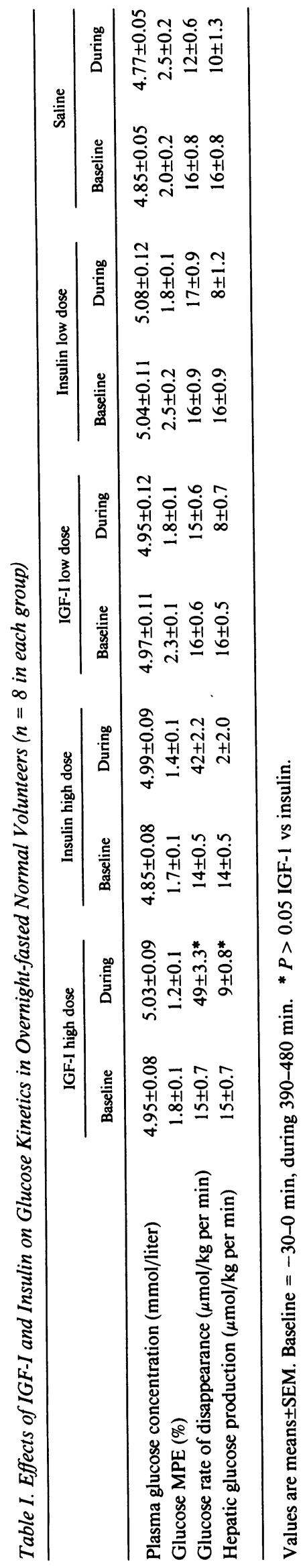

IGF-I ( low dose group), or saline ( $0.15 \mathrm{mmol} \mathrm{NaCl}$; group 3); variable rates of $20 \%$ glucose (Hausmann Laboratorien, St. Gallen, Switzerland) were infused to maintain plasma glucose concentrations at baseline levels (10). Each subject receiving IGF-I was studied a second time $\sim 6$ wk later with insulin; the insulin infusion rates were adjusted in $\sim$ 30-min intervals to achieve similar glucose infusion rates during clamping as during his preceding IGF-I study. The glucose $20 \%$ infusate contained $1.2 \%\left[6,6-D_{2}\right]$ glucose (variable $\left[D_{2}\right]$ glucose infusion) to maintain $\left[D_{2}\right]$ glucose mole percent excess during clamping, thus avoiding "negative" rates of hepatic glucose production (11). Recombinant human IGF-I (gift from Ciba-Geigy, Basel, Switzerland) or insulin (Actrapid HM; Novo Nordisk, Bagsvaerd, Denmark) were mixed in saline with $2 \mathrm{ml}$ of the subject's own blood. IGF-I was started with priming rates during the initial $45 \mathrm{~min}$ ( $15 \mathrm{~min} 3 \times, 15 \mathrm{~min} 2 \times, 15 \mathrm{~min}$ $1.5 \times$ the final infusion rate), whereas insulin infusions were started with 0.52 and $0.065 \mathrm{nmol} / \mathrm{kg}$ per $\mathrm{h}$ during the high and low dose protocols, respectively. Plasma was rapidly obtained by refrigerated centrifugation $\left(4^{\circ} \mathrm{C}\right)$ and stored at $-70^{\circ} \mathrm{C}$ until later assay. Expired air was collected into gas-tight 20 -ml glass tubes (Vacutainer ${ }^{\otimes}$; Becton-Dickinson, Meylan, France) for later ${ }^{13} \mathrm{CO}_{2}$ analysis and into Douglas bags for determination of $\mathrm{CO}_{2}\left(\mathrm{VCO}_{2}\right)$ and $\mathrm{O}_{2}$ content $\left(\mathrm{VO}_{2}\right)$ by infrared gas analysis (E. Jäger, Würzburg, Germany). Respiratory volume per time unit was measured using a respirometer (Spiroflo III; Rotamed, Port Talbot, United Kingdom).

Analytical methods. Plasma glucose concentration was measured instantaneously using glucose oxidase and a hydrogen peroxide sensor (Yellow Springs Instrument Co., Yellow Springs Glucose Analyzer model 23AM; Yellow Springs, $\mathrm{OH})$. Plasma $\left[\mathrm{D}_{2}\right]$ glucose enrichment (12), plasma leucine and $\alpha$-KIC concentration and isotopic enrichment were measured by gas chromatography-mass spectrometry (GCMS) selected ion monitoring (model 5890/5790; Hewlett-Packard Co., Palo Alto, CA ). $\left[D_{10}\right]$ leucine and $\left[D_{7}\right] \alpha-K I C$ were used as internal standards (13). All tracer infusates were ultrafiltrated $(0.1 \mu \mathrm{m})$ and analyzed by gas chromatography-mass spectrometry for chemical purity, tracer concentration, and isotope enrichment. Isotopic enrichment of ${ }^{13} \mathrm{CO}_{2}$ in breath was measured by isotope ratio mass spectrometry (Sera Series II; VG Isotech, Cheshire, United Kingdom). Plasma insulin was measured using a RIA kit from CIS International (Gif-SurYvette Cedex, France). Plasma total IGF-I was extracted and measured as described (14). Plasma C-peptide was determined by RIA, using reagents from Novo Research Institute (Bagsvaerd, Denmark). Glycan-coated Norit A carbon was used for precipitation (15). Plasma glucagon was measured by RIA, using antibody 4305 kindly provided by Dr. J. Holst (Panum Institute, Copenhagen, Denmark) (16), using the same precipitation technique. Total plasma free fatty acids (17) and $\beta$-hydroxybutyrate (18) were determined using enzymatic methods. Plasma acetoacetate was determined by gas chromatography headspace analysis using a gas chromatograph from Packard Instrument Co., Inc. (Meriden, CT) (19).

Calculations. Glucose rate of appearance was calculated during the baseline period and during the last $90 \mathrm{~min}$ of the clamp (steady state periods) by dividing the isotope infusion rate by the plasma $\left[6,6-D_{2}\right]-$ glucose mole percent excess (MPE) and subtracting the $\left[D_{2}\right]$ glucose infusion rate. Hepatic glucose production was calculated by subtracting the total amount of infused glucose from the glucose rate of appearance. Whole body leucine flux was calculated by dividing the isotope infusion rate by the plasma $\left[{ }^{13} \mathrm{C}\right] \alpha$-KIC MPE using the reciprocal pool model and subtracting the tracer infusion rate $(20)$. Steady state conditions were present during the 30 -min baseline period and during the last $90 \mathrm{~min}$ of IGF-I infusion, since there were no significant changes of $\left[{ }^{13} \mathrm{C}\right] \alpha$-KIC MPE with time during these periods (ANOVA). The rate of leucine oxidation was calculated in the same two study periods as:

Leucine oxidation $=\frac{\mathrm{APE}_{\mathrm{CO}_{2}} \times \dot{\mathrm{VCO}}_{2}}{\mathrm{MPE}_{\alpha-\mathrm{KIC}} \times 0.81}$,

where $\mathrm{APE} \mathrm{CO}_{2}$ is the ${ }^{13} \mathrm{C}$ atom percent excess in expired $\mathrm{CO}_{2}, \mathrm{VCO}_{2}$ the rate of total $\mathrm{CO}_{2}$ production, and MPE $\alpha$-KIC is the $\left[{ }^{13} \mathrm{C}\right]$ enrichment in arterialized plasma $\alpha$-KIC (20-22). 0.81 was used to correct for $\mathrm{CO}_{2}$ 
retention and other losses (23). The calculation of leucine oxidation may be in error if background ${ }^{13} \mathrm{CO}_{2}$ production changed during an experiment; e.g., caused by oxidation of infused glucose with a different natural ${ }^{13} \mathrm{C}$ content than the $\mathrm{CO}_{2}$ produced by the volunteer during the baseline period. To assess this question, background ${ }^{13} \mathrm{CO}_{2}$ enrichment was determined in four volunteers receiving high doses of insulin and glucose but no $\left[{ }^{13} \mathrm{C}\right]$ leucine tracer infusions. The results demonstrated that background ${ }^{13} \mathrm{CO}_{2}$ enrichment increased modestly during $8 \mathrm{~h}$ of glucose infusion; if these background changes were included in the calculation of leucine oxidation, it decreased by $40 \%$ rather than by $34 \%$ during high doses of insulin, and by $61 \%$ instead of $55 \%$ during IGF-I. Thus, this effect of glucose infusions resulted in a modest augmentation of the effects of insulin and IGF-I on leucine oxidation.

Nonoxidative leucine flux was calculated by subtracting the rate of leucine oxidation from whole body leucine flux. Leucine rate of appearance (equalling disappearance) was calculated using the primary pool model by dividing the isotope infusion rate with the plasma $\left[{ }^{13} \mathrm{C}\right]-$ leucine MPE and subtracting the tracer infusion rate (22). The metabolic clearance rates of IGF-I and insulin were the ratios of their infusion rates and their increases in plasma concentrations at the end of the studies.

Statistical analyses. One-way ANOVA with repeated measures (Macintosh II; Statview II, Berkeley, CA) was used to detect changes of parameters over time. Differences between protocols were compared using two-way ANOVA. Baseline values $(-30,-15$, and $0 \mathrm{~min}$ ) were compared with $390,420,450$, and 480 min values, and the interaction of the two treatments was tested.

\section{Results}

Plasma glucose concentrations, glucose infusion rate, hepatic glucose production, and glucose rate of disappearance. Plasma glucose concentrations during the baseline period averaged $4.97 \mathrm{mmol} /$ liter and were similar in all groups ( Table I). Mean changes of plasma glucose concentrations from baseline during the clamp period were $<10 \%$ in all groups. Fig. 1 demonstrates that glucose infusion rates during $480 \mathrm{~min}$ of glucose clamping were similar during the two corresponding doses of IGF-I and insulin. The insulin doses matching high and low IGF-I doses were $0.226 \pm 0.02 \mathrm{nmol} / \mathrm{kg}$ per $\mathrm{h}$ and $0.035 \pm 0.004 \mathrm{nmol} / \mathrm{kg}$ per $\mathrm{h}$ insulin, respectively. Hepatic glucose production was more suppressed during high dose insulin ( -89 vs $-35 \%, P$ $=0.003$ ), whereas glucose rate of disappearance increased more during high dose IGF-I than during administration of the compared hormone ( 239 vs $197 \%, P=0.021$ ). During low dose IGF-I and insulin, the changes of glucose production and disappearance were similar. A small amount of glucose was also needed during clamping in saline controls.

Plasma leucine and plasma $\alpha$-ketoisocaproate concentrations, whole body leucine flux, leucine oxidation rate, and leucine nonoxidative rate of disappearance. Table II demonstrates that there were significant decreases of plasma leucine, and to a lesser extent, of $\alpha$-KIC concentrations during high and low doses of IGF-I and insulin ( $P=0.0001)$, respectively (IGF-I vs insulin: NS). Whole body leucine flux (Fig. 2) decreased from basal rates by $42 \pm 4 \%(P=0.0001)$ and by $32 \pm 3 \%(P=0.0001)$ during the high IGF-I and insulin doses, respectively (IGF-I vs insulin, $P=0.008$ ). Leucine flux during low doses decreased less than during high doses. Leucine oxidation decreased by $55 \pm 4 \%(P=0.0001)$ and by $33 \pm 6 \%(P=0.0001)$ after high doses of IGF-I and insulin, respectively (IGF-I vs insulin: $P$ $=0.0001$ ); the decreases were similar during low doses and during saline infusion. Leucine nonoxidative rate of disappearance decreased more during high than during low doses $(P$ $<0.001$ ) but without significant difference between the two

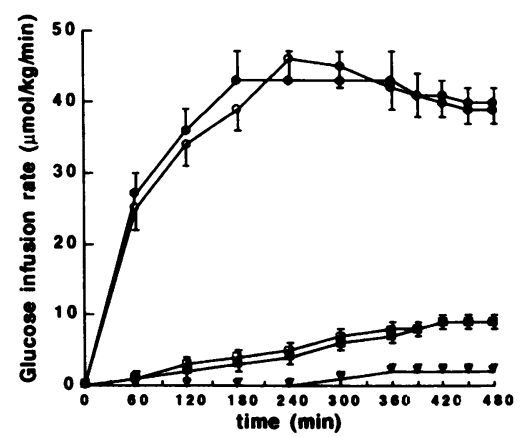

Figure 1. (A) Glucose infusion rate during 480 min of euglycemic clamping, (B) hepatic

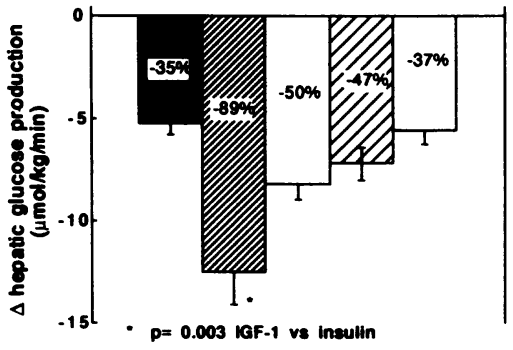
glucose production, and (C) glucose rate of disappearance expressed as changes of final period (390-480 min of hormone or saline infusion) from baseline. Results are means \pm SEM of $n$ $=8$ in each group. In $A$ : $\longrightarrow$, IGF-I "high" dose; $\bigcirc-$, insulin (2390m "high" dose; $\longrightarrow$, IGF-I "low" dose; $\longrightarrow$, insulin "low" dose; $\longrightarrow$, saline. In $B$ and $C$ (from left to right): a IGF-I "high" dose; $\square$, insulin "high" dose; $\square$, IGF-I "low" dose; $\square$, insulin "low" dose; $\square$, saline.

peptides. Leucine rate of appearance calculated by the primary pool model (Table II) decreased more during high doses of IGF-I than during insulin $(P=0.013)$.

Plasma free fatty acid and ketone body concentrations. Plasma free fatty acid concentrations (Fig. 3) decreased similarly (by $44 \pm 4$ by $50 \pm 4 \%$ ) after $480 \mathrm{~min}$ of IGF-I and insulin infused at high doses; they remained similar to baseline values at the end of low doses, after a transient increase from 0 to 240 min after IGF-I $(P<0.05$ IGF-I vs insulin $)$. Plasma free fatty acid concentrations in saline controls increased by $68 \pm 12 \%(P$ $=0.0001$ ). The course of ketone body concentrations paralleled that of FFA; plasma acetoacetate concentrations decreased from baseline by $73 \pm 9$ and $75 \pm 7 \%$ until the end of high dose IGF-I and insulin, respectively, and less (by $34 \pm 9$ and $37 \pm 14 \%, P<0.001$ vs high doses) during low doses. Plasma B-hydroxybutyrate concentrations decreased in parallel by $32 \pm 10$ and by $31 \pm 8 \%$ during high IGF-I and insulin doses, respectively, whereas they were similar to baseline values at the end of low doses, after a transient increase from 0 to $240 \mathrm{~min}$ during IGF-I $(P<0.05$ vs insulin $)$. Plasma acetoacetate increased in saline controls by $113 \pm 29 \%$, and B-hydroxybutyrate by $221 \pm 68 \%$.

Plasma insulin, IGF-I, C-peptide, and glucagon concentrations. Plasma insulin concentrations (Fig. 4) increased during high and low insulin doses 5.6- and 1.6-fold above baseline values, whereas they decreased $(P<0.001)$ by $25 \pm 5$ and $22 \pm 4 \%$ during high and low IGF-I doses, respectively. Plasma total IGF-I concentrations increased during infusion to $360 \%$ of baseline at the end of high doses and to $150 \%$ after low doses. 


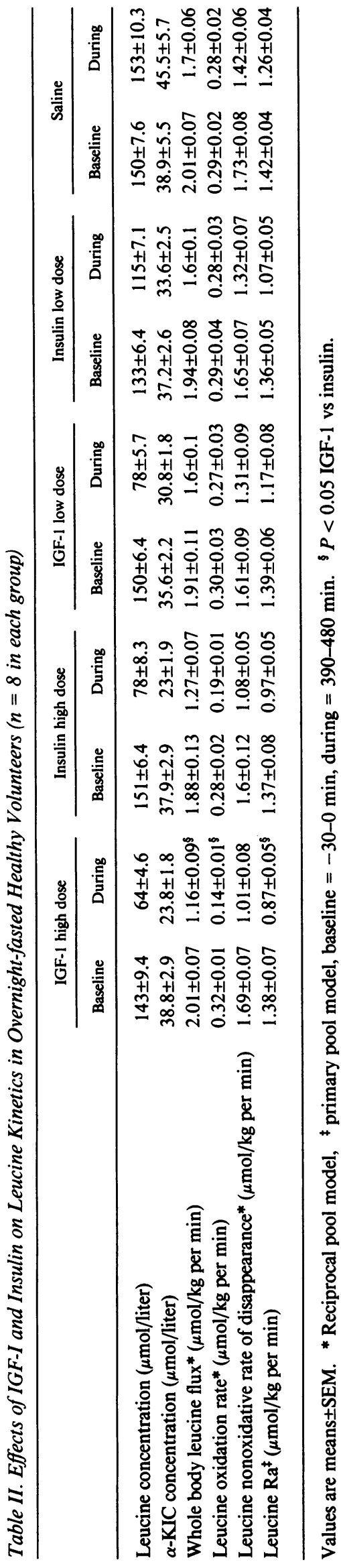

Metabolic clearance rates were estimated during low doses; they amounted to $19 \mathrm{ml} / \mathrm{kg}$ per $\mathrm{h}$ during administration of IGF-I and to $795 \mathrm{ml} / \mathrm{kg}$ per $\mathrm{h}$ during insulin. Plasma C-peptide concentrations at baseline were similar in all groups ( range of means $455-598 \mathrm{pmol} /$ liter); they decreased by $57 \pm 4 \%$ and less (by $36 \pm 6 \%, P<0.005$ ) during high doses of IGF-I, respectively. During low dose IGF-I, they decreased also compared to saline controls $(P<0.001)$. Baseline plasma glucagon concentrations were similar in all groups (range of means 54-67 $\mathrm{pmol} /$ liter $)$; they decreased $(P<0.001)$ similarly during high and low doses of IGF-I and insulin.

\section{Discussion}

Glucose kinetics. The hypoglycemic potency of IGF-I administered as bolus injection has been reported to be 12 -fold lower than that of insulin compared on a molar basis (3). In the present studies where constant infusions of the two peptides were used, their molar potency ratio was 17 during high doses and 16 during low doses. Since IGF-I is bound to specific binding proteins (24) that interfere with its biological activity and degradation, a comparison of the two peptides administered on a molar basis does not reflect true physiological potencies. Therefore, they were compared in the present studies at equipotent doses regarding glucose uptake, although IGF-I levels were $\sim 500$-fold higher than those of insulin. The present results demonstrated that acute increases in plasma concentrations of IGF-I decreased hepatic glucose output in man. The higher of the two doses of IGF-I studied suppressed hepatic glucose output significantly less than a corresponding dose of insulin ( $48 \mathrm{vs} 89 \%$ ). On the other hand, glucose rate of disappearance (reflecting mainly peripheral glucose utilization in muscle (25)) increased more during IGF-I than during insulin. Studies with IGF-I in rats and in depancreatized dogs demonstrated a relative insensitivity of hepatic glucose output to IGF$I(6,26)$. These and our findings are in agreement with differences in receptor distribution of IGF-I and insulin in humans and in experimental animals (27); i.e., higher concentrations of type I IGF-I receptors in muscle and relatively lower concentrations in liver. Hepatic glucose production was influenced by both infused IGF-I and endogenous insulin secretion. Since plasma C-peptide levels (and thus, presumably intraportal insulin concentrations) were lower during IGF-I than during insulin, it can not be excluded that this phenomenon contributed to diminished suppression of hepatic glucose production by IGF-I. However, C-peptide concentrations were lowered in both protocols, and it appeared unlikely that differences in endogenous insulin secretion explained entirely the distinctly diminished decrease of hepatic glucose output during high doses of IGF-I compared to high doses of insulin.

The observation of a relatively high sensitivity of hepatic glucose output to insulin compared to peripheral glucose utilization is consistent with earlier studies (28). The use of a variable tracer infusion rate during glucose clamping was probably the reason that "negative" rates of hepatic glucose output were avoided in the present studies and that "true" rates of glucose production were determined (11).

Leucine kinetics. After high doses of IGF-I leucine flux decreased by $43 \%$ and leucine oxidation even by $56 \%$. These findings suggest a potent inhibitory effect of IGF-I on protein breakdown and on irreversible loss of amino acids; these effects were significantly more pronounced than with corresponding 

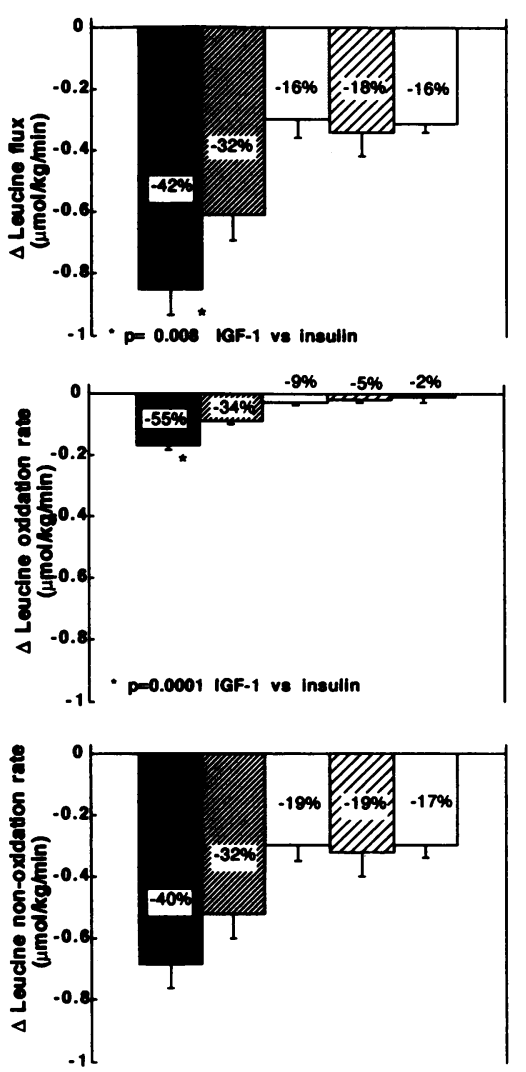

Figure 2. Whole body leucine flux, leucine oxidation rate, and leucine nonoxidation rate expressed as changes of final period $(390-480$ $\mathrm{min}$ ) from baseline. Results are means \pm SEM. - IGF-I "high" dose; $\mathbb{Z}$, insulin "high" dose; $\square$, IGF-I "low" dose; $\square$, insulin "low" dose; $\square$, saline.

doses of insulin. IGF-I at low doses had no significant effect on leucine kinetics when compared to controls. The data demonstrated that even in saline controls there was a decrease of leucine flux. It cannot be ruled out, however, that this decrease was in part caused by tracer recycling (29). Previous findings of IGF-I effects on leucine flux in experimental animals demonstrated conflicting results $(30,31)$. The observation that nonoxidative leucine flux decreased during IGF-I was unexpected and suggested inhibition of protein synthesis; however, the fall of plasma leucine concentrations caused by antiproteolysis and fasting may have prevented a possible stimulatory effect on protein synthesis as it has been reported with insulin (32). It remains to be seen whether IGF-I is capable of stimulating protein synthesis during concurrent administration of amino acids.

Lipid metabolism. Administration of IGF-I at either dose lowered plasma free fatty acid concentrations dose dependently, suggesting inhibition of lipolysis. In addition, the decreases of plasma acetoacetate and B-hydroxybutyrate concentrations reflected diminished ketogenesis. These effects of IGFI were not significantly different from those of corresponding doses of insulin at the end of the studies, in agreement with findings in humans (4), but at variance with data obtained in rats and dogs demonstrating higher sensitivity of lipolysis to insulin than to IGF-I $(6,31)$. In vitro studies demonstrated that type 1 IGF-I receptor concentrations were relatively high in human muscle but low in fat and liver $(27,33,34)$. Considering these data on IGF-I receptor distribution, the present observations of similar final effects of IGF-I and insulin on lipid metabolism suggest that they were mediated via insulin receptors. It is noteworthy that during the first $4 \mathrm{~h}$ of the study, low doses of IGF-I lowered FFA and ketone bodies significantly
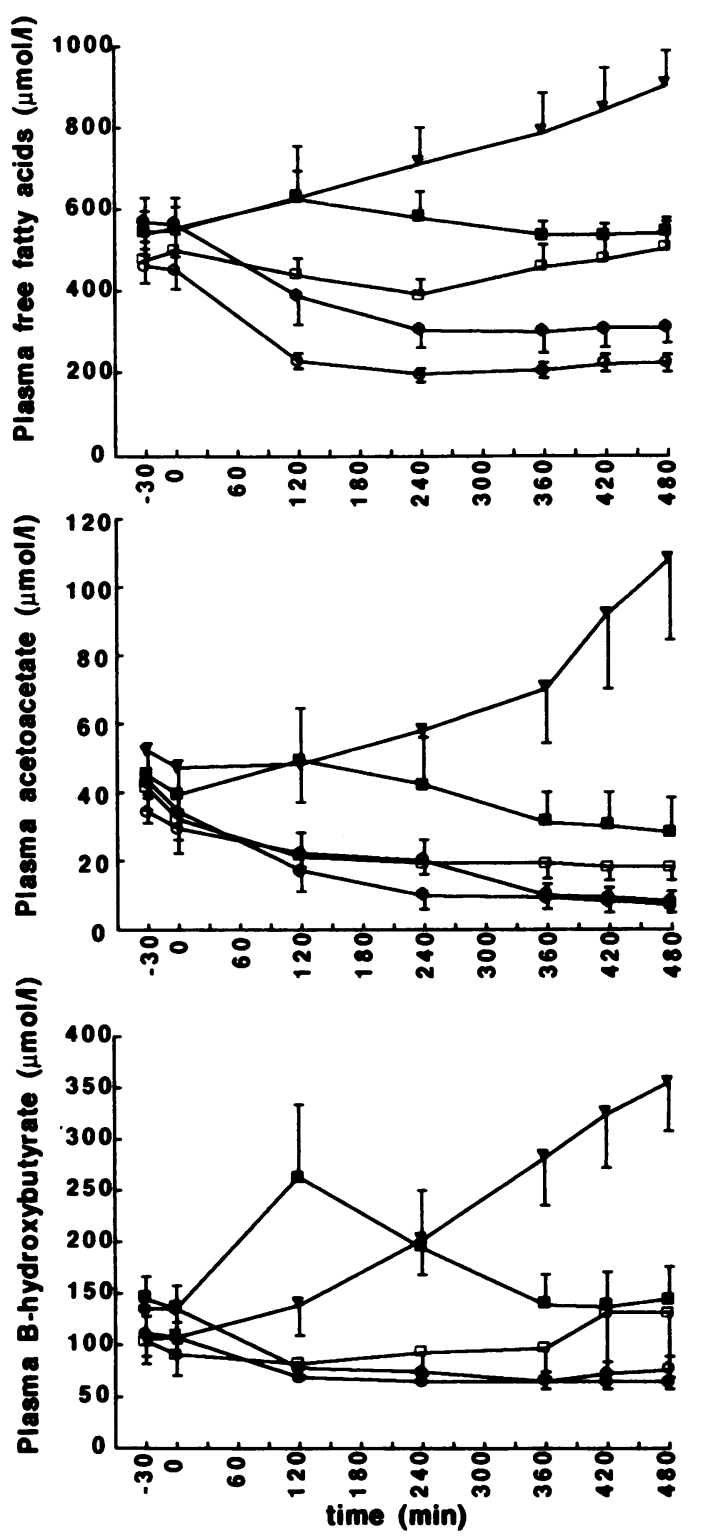

Figure 3. Plasma free fatty acids, plasma acetoacetate, and $\beta$-hydroxybutyrate concentrations. IGF-I, insulin, or saline were infused between 0 and $480 \mathrm{~min}$. Results are means \pm SEM. $\longrightarrow-$ - Saline; $\longrightarrow-$, IGF-I "high" dose; —- - insulin "high" dose; —-, IGF-I "low" dose; $\multimap \square-$, insulin "low" dose.

less than insulin. A possible explanation for this phenomenon may be that IGF-I concentrations increase only slowly in adipose tissue to activate insulin receptors. The fact that plasma FFA were similar after IGF-I and insulin indicate that FFA availability did not explain the present results of leucine kinetics; this is of interest, since FFA concentrations have been reported to influence leucine oxidation (35).

Glucoregulatory hormones. Acute increases in plasma concentrations of IGF-I lowered plasma insulin and C-peptide levels, in agreement with previous studies $(4,5,31,36,37)$. The fall of plasma C-peptide during high doses of IGF-I was more pronounced than that during insulin ( 57 vs $36 \%$ ), suggesting increased inhibition of insulin secretion by exogenous IGF-I compared to insulin. Suppression of insulin secretion by IGF-I 

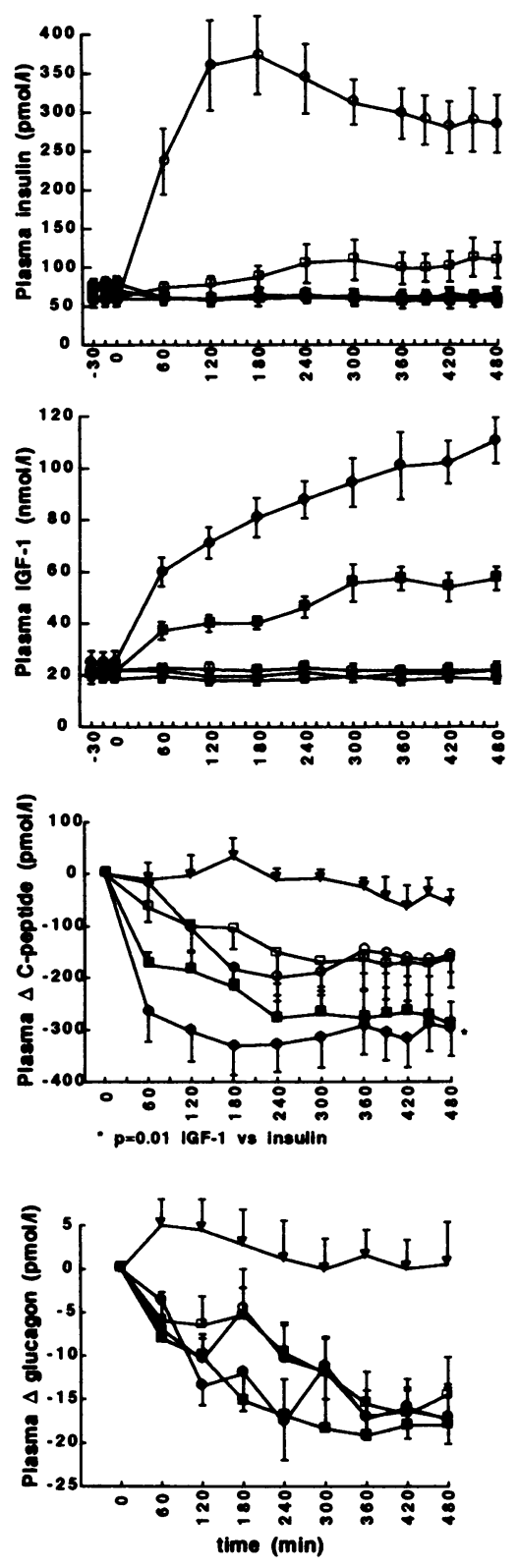

may have resulted in lower intraportal insulin levels, and thus in diminished suppression of hepatic glucose production by insulin (38); this effect may have confounded a lowering of hepatic glucose output by IGF-I. Along the same line, it is possible that the decrease of plasma insulin by IGF-I led to an underestimation of the antiproteolytic effect of IGF-I (32). Plasma concentrations of IGF-I during high doses were similar to those observed in pathophysiological conditions such as acromegaly (39); binding protein patterns, however, were probably entirely different $(40,41)$. The lowering effects of IGF-I and insulin on plasma glucagon concentrations were similar after high and low doses. These data indicate that IGF-I effects on hepatic glucose production were not confounded by altered circulating glucagon levels.

Conclusions. The preferential stimulation of peripheral glucose uptake and inhibition of leucine flux and oxidation by IGF-I compared to insulin suggests that this peptide may be of therapeutical interest in conditions of peripheral insulin resistance and in protein catabolism.

\section{Acknowledgments}

We would like to thank Ms. H. Bodmer, Ms. K. Dembinsky, Ms. A. Oberhänsli, Mr. N. Sansano, and Ms. S. Vosmeer for technical assistance. Dr. K. Müller of Ciba-Geigy kindly performed the IGF-I assay.

This work was supported by grants from the Swiss National Science Foundation (no. 32-289908.90) and from Ciba-Geigy, Basel.

\section{References}

1. Froesch, E. R., and J. Zapf. 1985. Insulin-like growth factors and insulin: comparative aspects. Diabetologia. 28:485-493.

2. Czech, M. P. 1982. Structural and functional homologies in the receptors for insulin and the insulin-like growth factors. Cell. 31:8-10.

3. Guler, H., J. Zapf, and E. R. Froesch. 1987. Short-term metabolic effects of recombinant human insulin-like growth factor $\mathrm{I}$ in healthy adults. $N$. Engl. $J$. Med. 317:137-140.

4. Boulware, S. D., W. V. Tamborlane, L. S. Matthews, and R. S. Sherwin. 1992. Diverse effects of insulin-like growth factor 1 on glucose, lipid and amino acid metabolism. Am. J. Physiol. 262:E130-E133.

5. Turkalj, I., U. Keller, R. Ninnis, S. Vosmeer, and W. Stauffacher. 1992. Effects of increasing doses of recombinant human insulin-like growth factor-1 on glucose, lipid and leucine metabolism in man. J. Clin. Endocrinol. \& Metab. 75:1186-1191.

6. Giacca, A., R. Gupta, S. Effendic, K. Hall, A. Skottner, L. Lickley, and M. Vranic. 1990. Differential effects of IGF-I and insulin on glucoregulation and fat metabolism in depancreatized dogs. Diabetes. 39:340-347.

7. Bolinder, J., A. Lindblad, P. Engfeldt, and P. Arner. 1987. Studies of acute effects of insulin-like growth factors I and II in human fat cells. J. Clin. Endocrinol. \& Metab. 65:732-737.

8. Moxley, R. T., P. Arner, A. Moss, A. Skottner, M. Fox, D. James, and M. Livingston. 1990. Acute effects of insulin-like growth factor I and insulin on glucose metabolism in vivo. Am. J. Physiol. 59:561-567.

9. McGuire, E., J. Helderman, J. Tobin, R. Andres, and M. Berman. 1976. Effects of arterial versus venous sampling on analysis of glucose kinetics in man. J. Appl. Physiol. 41:565-573.

10. DeFronzo, R. A., J. D. Tobin, and R. Andres. 1979. Glucose clamp technique: a method for quantifying insulin secretion and resistance. Am. J. Physiol. 237:E214-223.

11. Molina, M. J., A. D. Baron, S. V. Edelmann, G. Brechtel, P. Wallace, and J. M. Olefsky. 1990. Use of a variable tracer infusion method to determine glucose turnover in humans. Am. J. Physiol. 258:E16-E23.

12. Küry, D., and U. Keller. 1991 . Trimethylsilyl- $O$-methyloxime derivatives for the measurement of [6,6- $\left.\mathrm{d}_{2}\right]$-D-glucose enriched plasma samples using gas chromatography-mass spectroscopy. J. Chromatogr. 572:302-306.

13. Schwenk, W. F., P. F. Berg, B. Beaufrère, J. M. Miles, and M. W. Haymond. 1984. Use of T-butyldimethylsilylation in the gas chromatographic-mass spectrometric analysis of physiologic compounds found in plasma using electronimpact ionization. Anal. Biochem. 141:101-109.

14. Zapf, J., H. Walter, and E. R. Froesch. 1981. Radioimmunological determination of insulin-like growth factors I and II in normal and in patients with growth disorders and extrapancreatic tumor hypoglycemia. J. Clin. Invest. 68:1321-1330.

15. Herbert, V., L. Kam-Seng, C. W. Gottlieb, and S. J. Bleicher. 1965. Coated charcoal immunoassay of insulin. J. Clin. Endocrinol. 25:1375-1384.

16. Holst, J. J., and B. Aasted. 1974. Production and evaluation of glucagon antibodies for radioimmunoassay. Acta Endocrinol. 77:715-726.

17. Miles, J., R. Glasscock, J. Aikens, J. Gerich, and M. Haymond. 1983. A microfluorometric method for the determination of free fatty acids in plasma. $J$. Lipid Res. 24:96-99.

18. Williamson, D. H., and J. Mellanby. 1974. D-(-)-3-hydroxybutyrat. In Methoden der enzymatischen Analyse. H. Bergmeyer, editor. Springer-Verlag, Berlin. pp. 1883-1886.

19. Van Stekelenburg, G. J., and J. W. De Bruyn. 1970. A simple gas chromatographic determination of acetone and $\beta$-ketobutyric acid in blood serum by means of head space gas sampling. Clin. Chim. Acta 28:233-237.

20. Schwenk, W. F., B. Beaufrère, and M. W. Haymond. 1985. Use of reciprocal pool specific activities to model leucine metabolism in humans. Am. J. Physiol. 249:E646-650.

21. Beaufrère, B., F. Horber, F. W. Schwenk, H. M. Marsh, D. Matthews, J. E. Gerich, and M. W. Haymond. 1989. Glucocorticosteroids increase leucine oxidation and impair leucine balance in humans. Am. J. Physiol. 257:E712-E721. 
22. Horber, F. H., C. M. Horber-Feyder, S. Krayer, F. Schwenk, and M. Hamond. 1989. Plasma reciprocal pool specific activity predicts that of intracellular free leucine for protein synthesis. Am. J. Physiol. 257:E385-E399.

23. Allsop, J. R., R. R. Wolfe, and J. F. Burke. 1978. Tracer priming the bicarbonate pool. J. Appl. Physiol. 45:137-139.

24. Guler, H. P., J. Zapf, C. Schmid, and E. R. Froesch. 1989. Insulin-like growth factors I and II in healthy man. Estimation of half-lives and production rates. Acta Endocrinol. 121:753-758.

25. DeFronzo, R. A., R. Gunnarsson, O. Björkman, M. Olsson, and J. Wahren. 1985. Effects of insulin on peripheral and splanchnic glucose metabolism in noninsulin-dependent ( Type II) diabetes mellitus. J. Clin. Invest. 76:149155.

26. Jacob, R. J., R. S. Sherwin, L. Bowen, D. Fryburg, K. D. Fagin, W. V. Tamborlane, and G. I. Shulman. 1991. Metabolic effects of IGF-I and insulin in spontaneously diabetic BB/w rats. Am. J. Physiol. 260:E262-268.

27. Caro, J. F., J. Poulos, O. Ittrop, H. Lithell, and P. Arner. 1988. Insulin-like growth factor I binding in hepatocytes from human liver, human hepatoma, and normal, regenerating, and fetal rat liver. J. Clin. Invest. 81:976-981.

28. Rizza, R. A., L. J. Mandarino, and J. E. Gerich. 1981. Dose-response characteristics for effects of insulin on production and utilization of glucose in man. Am. J. Physiol. 240:E630-E639.

29. Schwenk, W. F., E. Tsalikian, B. Beaufrère, and M. W. Haymond. 1985. Recycling of an amino acid label with prolonged isotope infusion: implications for kinetic studies. Am. J. Physiol. 248:E482-E487.

30. Douglas, R. G., P. D. Gluckman, K. Ball, B. Breier, and J. H. F. Shaw. 1991. The effects of infusion of insulin-like growth factor (IGF) I and IGF-II, and insulin on glucose and protein metabolism in fasted lambs. J. Clin. Invest. 88:614-622.

31. Jacob, R., E. Barrett, G. Plewe, K. D. Fagin, and R. S. Sherwin. 1989. Acute effects of insulin-like growth factor $I$ on glucose and amino acid metabolism in the awake fasted rat. J. Clin. Invest. 83:1717-1723.

32. Fukagawa, N. K., K. L. Minaker, V. R. Young, D. E. Matthews, D. M Bier, and J. W. Rowe. 1989. Leucine metabolism in aging humans: effect of insulin and substrate availability. Am. J. Physiol. 256:E288-E294.
33. Livingston, N., T. Pollare, H. Lithell, and P. Arner. 1988. Characterization of insulin-like growth factor I receptors in sceletal muscle of normal and insulin resistant subjects. Diabetologia. 31:871-877.

34. Zorzano, A., D. E. James, N. B. Ruderman, and P. F. Pilch. 1988. Insulinlike growth factor I binding and receptor kinase in red and white muscle. FEBS (Fed. Eur. Biochem. Soc.) Lett. 234:257-262.

35. Beaufrère B., D. Chassard, C. Broussolle, J. P. Riou, and M. Beylot. 1992. Effects of D-B-hydroxybutyrate and long- and medium-chain triglycerides on leucine metabolism in humans. Am. J. Physiol. 262:E268-E274.

36. Zenobi, P. D., S. Graf, H. Ursprung, and E. R. Froesch. 1992. Effects of insulin-like growth factor-I on glucose tolerance, insulin levels, and insulin secretion. J. Clin. Invest. 89:1908-1913.

37. Guler, H. P., C. Schmid, J. Zapf, and E. Froesch. 1986. Effects of recombinant insulin-like growth factor-I on insulin secretion and renal function in normal human subjects. Proc. Natl. Acad. Sci. USA. 86:2868.

38. Cherrington, A. D., J. L. Chaisson, J. E. Liljenquist, A. S. Jemmings, U. Keller, and W. W. Lacy. 1976. The role of glucagon and insulin in the regulation of basal glucose production in the postabsorptive dog. J. Clin. Invest. 58:14071418.

39. Barakan, A. L., I. Z. Beintins, and R. P. Kelch. 1988. Plasma insulin-like growth factor-I/somatomedin-C in acromegaly: correlation with the degree of growth hormone hypersecretion. J. Clin. Endocrinol. Metab. 67:69-73.

40. Hardouin, S., M. Gourmelen, P. Noguiez, D. Seurin, M. Roghani, Y. Le Bouc, G. Povoa, T. Merimee, P. Hossenlopp, and M. Binoux. 1989. Molecular forms of serum insulin-like growth factor (IGF-I)-binding proteins in man: relationship with growth hormone and IGFs and physiological significance. J. Clin. Endocr. Metab. 69:1291-1301.

41. Zapf, J., C. Schmid, H. P. Guler, C. Waldvogel, C. Hauri, E. Futo, P. Hossenlopp, M. Binoux, and E. R. Froesch. 1990. Regulation of binding proteins for insulin-like growth factors (IGF-I) in humans. Increased expression of IGF binding protein 2 during IGF I treatment of healthy adults and in patients with extrapancreatic tumor hypoglycemia. J. Clin. Invest. 86:952-961. 